\title{
Mendorong usaha tanaman kayu sebagai bisnis yang menarik bagi petani
}

\author{
Dede Rohadi, Tuti Herawati, Christine Padoch dan Digby Race
}

\section{Temuan kunci}

- Usaha tanaman kayu yang dilakukan petani pada umumnya belum sepenuhnya berorientasi pasar. Akibatnya, petani sering kehilangan peluang dalam memperoleh penghasilan yang lebih baik.

- Tanaman kayu berperan penting sebagai sumber pendapatan petani. Di Kabupaten Gunungkidul, nilai penjualan kayu rakyat memberikan kontribusi sebesar 15\% dari pendapatan total keluarga petani .

- Harga kayu rakyat sangat bervariasi di setiap lokasi, namun harga di tingkat petani pada umumnya berada pada kisaran terendah. Hal ini disebabkan oleh: (i) kualitas kayu yang rendah; (ii) posisi tawar petani yang rendah; dan (iii) biaya transaksi tinggi yang disebabkan oleh peraturan tata niaga kayu.

- Lembaga pemerintah yang bertanggung jawab dalam penyelenggaraan program penyuluhan perlu meningkatkan kapasitas petani dalam menjalankan usaha tanaman kayu . Kapasitas yang perlu ditingkatkan meliputi:

pengetahuan petani tentang pasar, harga dan standar kualitas kayu;

keterampilan teknik budidaya kayu, terutama penjarangan dan pemangkasan tanaman kayu;

pemasaran kayu secara kolektif dan pengembangan kemitraan usaha dengan industri kayu.

- Untuk mengurangi biaya transaksi dalam pemasaran kayu, pemerintah pusat dan daerah perlu menyederhanakan peraturan tata niaga kayu rakyat. Sertifikasi kayu, seperti Sistem Verifikasi Legalitas Kayu (SVLK) harus memberikan insentif yang jelas bagi petani dan sekaligus dapat digunakan sebagai pengganti dokumen SKAU (Surat Keterangan Asal Usul).

\section{Pendahuluan}

Tanaman kayu rakyat di Indonesia dapat dijumpai dalam berbagai bentuk. Petani menanam tanaman kayu di lahan milik dalam bentuk hutan rakyat atau di lahan hutan negara melalui berbagai skema perhutanan sosial, seperti Hutan Tanaman Rakyat (HTR), Hutan Kemasyarakatan (HKm) atau Hutan Desa (HD). Terlepas dari berbagai bentuk pengelolaannya, petani merupakan pelaku utama dari usaha tanaman kayu tersebut. Keputusan petani di dalam melakukan usaha sangat menentukan manfaat yang akan mereka terima.

Tanaman kayu rakyat memegang peranan penting dalam pembangunan kehutanan di Indonesia. Berbagai inisiatif telah dilakukan oleh pemerintah melalui berbagai program dan kegiatan perhutanan sosial. Program-program tersebut bertujuan untuk mengurangi kemiskinan, khususnya di wilayah pedesaan, meningkatkan jumlah tutupan hutan dan meningkatkan pasokan kayu untuk kebutuhan industri (Peraturan Menteri Kehutanan No. P.01/2004').

\footnotetext{
1 Peraturan Menteri Kehutanan No. P.01/2004 tentang pemberdayaan masyarakat di dalam dan sekitar hutan melalui Social Forestry, pasal 1 ayat (5) menyebutkan "Social Forestry adalah sistem pengelolaan sumberdaya hutan pada kawasan hutan negara dan atau hutan hak, yang memberi kesempatan kepada masyarakat setempat sebagai pelaku dan atau mitra utama dalam rangka meningkatkan kesejahteraannya dan mewujudkan kelestarian hutan".
}

Sekalipun upaya pengembangan tanaman kayu rakyat telah banyak dilakukan di seluruh wilayah Indonesia, namun perkembangan jumlah areal tanaman hingga saat ini masih sangat rendah. Luas total tanaman kayu rakyat saat ini sekitar 2,8 juta hektar (Roadmap Industri Kehutanan, 2013²) yang sebagian besar berupa hutan rakyat. Sementara luas hutan tanaman rakyat

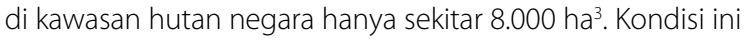
menunjukkan bahwa petani belum menganggap usaha tanaman kayu sebagai peluang usaha yang menguntungkan.

Kegiatan penelitian baru-baru ini telah mengidentifikasi berbagai tantangan yang membuat petani sulit memperoleh hasil yang maksimal dari usaha tanaman kayu mereka, yaitu:

1. Petani kayu rakyat cenderung hanya menerima harga yang ditentukan pembeli kayu (price taker) karena rendahnya akses pasar, keterampilan usaha dan terbatasnya kapasitas dalam menerapkan praktik silvikultur yang baik. Faktor-faktor tersebut melemahkan posisi tawar mereka.

2. Petani dibatasi oleh berbagai aturan tata niaga kayu yang menyebabkan biaya transaksi tinggi.

\footnotetext{
2 Disampaikan oleh Direktur Jenderal Bina Usaha Kehutanan dalam diskusi panel "Menjawab Tantangan Indonesia Raja Kayu Dunia", Jakarta, 22 Mei 2014.

3 Berdasarkan data Direktorat Jenderal Bina Usaha Kehutanan, bahwa areal HTR yang telah ditanam saat ini adalah 7.896 ha, atau sekitar 4\% dari total areal yang telah berizin, atau sekitar $1 \%$ dari total areal yang dialokasikan untuk program HTR.
} 


\section{Usaha tanaman kayu dalam struktur pendapatan petani}

Pemerintah dan berbagai lembaga pengembangan lainnya perlu memahami dengan baik peran tanaman kayu rakyat di dalam struktur pendapatan rumah tangga petani. Sebuah hasil penelitian (Rohadi et.al, 2012) menyimpulkan bahwa sekalipun kayu bukan merupakan sumber pendapatan utama bagi keluarga petani, namun memberikan peranan penting terhadap pendapatan mereka. Hasil penjualan kayu menyumbang sekitar 15\% dari total pendapatan rumah tangga (Gambar 1). Di beberapa wilayah, khususnya di Jawa, petani memandang kayu sebagai salah satu elemen penting dalam sistem pertanian mereka. Di Kabupaten Gunungkidul (Jawa), sekalipun lahan petani sangat terbatas, petani tetap mengalokasikan lebih dari 10\% area lahannya untuk ditanami berbagai jenis tanaman kayu, khususnya jati (Tectona grandis).

Sebuah proyek penelitian tentang bisnis kehutanan berbasis masyarakat (Community Based-Commercial Forestry/CBCF Project) telah melakukan analisis dimensi sosial dan penilaian atas kerangka kerja penghidupan masyarakat di lima kabupaten di Indonesia, yaitu Kabupaten Gunungkidul, Pati, Sumbawa, Bulukumba dan Konawe Selatan. Hasil penelitian menunjukkan bahwa kontribusi hasil penjualan kayu terhadap pendapatan keluarga cenderung lebih tinggi pada kalangan petani menengah dan kaya (van de Fliert, 2013; Oktalina et al, 2014). Hal ini menunjukkan bahwa bisnis tanaman kayu semakin dinilai penting oleh kelompok petani yang memiliki tingkat pendapatan yang lebih baik

Kegiatan menanam kayu sudah menjadi tradisi beberapa kelompok masyarakat, dimana budaya ini telah diturunkan dari generasi ke generasi. Petani juga memandang kegiatan penanaman kayu sebagai kegiatan penting untuk meningkatkan kualitas lingkungan dan status sosial mereka. Disamping itu petani sering mendapat dukungan dari pihak lain untuk melakukan kegiatan penanaman kayu, baik yang berasal dari program pemerintah maupun kegiatan investasi perusahaan swasta.

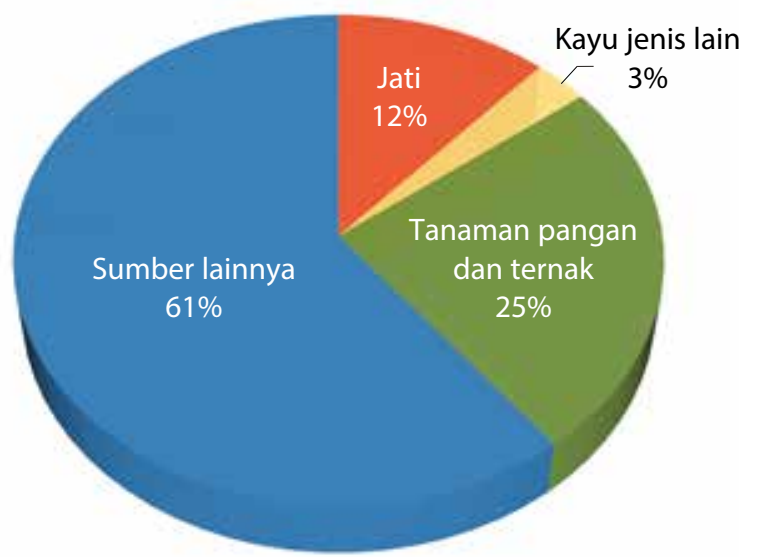

Gambar 1. Rata-rata kontribusi usaha tanaman kayu terhadap struktur pendapatan petani (berdasarkan hasi wawancara terhadap 31 responden petani di Kabupaten Gunungkidul, Yogyakarta; Rohadi et al, 2012)

\section{Tantangan bagi usaha tanaman kayu rakyat}

Berbagai hasil penelitian menunjukkan bahwa petani mengelola tanaman kayu mereka dengan cara yang tradisional, khususnya jika dilihat dari sudut pandang bisnis. Akibat keterbatasan akses terhadap fasilitas kredit, sebagian besar petani melakukan praktik tebang butuh dan dalam proses penjualannya mereka lebih fokus terhadap jumlah uang yang mereka perlukan daripada mempertimbangkan harga kayu yang berlaku. Kebutuhan yang mendesak akan uang tunai juga sering memaksa petani untuk menebang kayunya sebelum pohon mencapai umur dan ukuran yang optimum untuk dijual (Rohadi et al, 2012; Stewart et al, 2014a).

Petani menjual kayu mereka dalam bentuk pohon berdiri. Mereka pada umumnya tidak memiliki keterampilan dan modal yang cukup untuk melakukan pemanenan sendiri dan menjualnya secara langsung ke pedagang kayu (depo kayu) atau ke sawmills (kilang penggergajian). Selain itu, kayu yang dihasilkan petani cenderung berkualitas rendah karena ukuran diameternya kecil, batang tidak lurus dan banyak memiliki cacat mata kayu. Hal ini disebabkan karena petani pada umumnya tidak menerapkan teknik silvikultur yang baik, khususnya penjarangan dan pemangkasan (Rohadi et al. 2012; Stewart et al. 2014a)

Kaum lelaki sering terlibat lebih dominan di dalam kegiatan penanaman kayu dibanding kaum perempuan. Namun demikian, kaum perempuan berperan sangat penting dalam pengelolaan keuangan dari hasil penjualan kayu. Di samping itu, kaum perempuan juga memiliki peran besar dalam kegiatan pengelolaan hasil hutan bukan kayu (HHBK)

Ketika petani bekerja secara individu, mereka memiliki posisi yang lemah dalam proses penjualan kayu. Akan tetapi, penjualan kayu secara berkelompok masih sangat jarang dijumpai di Indonesia. Hal ini disebabkan karena faktor keterbatasan petani dalam mengelola organisasi, kurangnya bimbingan penyuluhan, dan kurangnya rasa saling percaya di antara anggota kelompok (van de Fliert et al, 2013)

\section{Pemasaran kayu rakyat}

Kegiatan penelitian pada Proyek CBCF telah mengkaji rantai nilai kayu rakyat. Hasil analisis menunjukkan bahwa untuk setiap jenis kayu, harga kayu rakyat sangat bervariasi tergantung kualitasnya. Harga kayu jati di lima lokasi penelitian berkisar antara Rp 500.000 hingga Rp 5 juta per $\mathrm{m}^{3}$. Harga kayu sengon (Paraserianthes falcataria (L.) Nielsen) bervariasi mulai dari Rp 395.000 hingga Rp 1,15 juta per $\mathrm{m}^{3}$. Tabel 1 menyajikan variasi harga kayu tersebut. Diameter dan bentuk batang (bebas dari cacat) merupakan faktor penting yang menentukan harga (Stewart et al, 2014a).

Hasil penelitian menunjukkan bahwa struktur pemasaran kayu rakyat, dalam hal jumlah dan keragaman pelaku pasar (pedagang perantara, kilang penggergajian dan pedagang besar) sangat bervariasi di setiap lokasi. Di Pulau Jawa, pasar relatif lebih berkembang dan cenderung mengarah kepada pasar bersaing sempurna. Jumlah pedagang perantara kayu di pulau Jawa (Gunungkidul dan Pati) lebih banyak dibandingkan dengan di luar Jawa (Sumbawa, Bulukumba dan Konawe Selatan). Gambar 2 menyajikan ilustrasi perbandingan rantai pemasaran kayu rakyat yang terjadi di Gunungkidul (di pulau Jawa) dan Sumbawa-Nusa Tenggara Barat (luar pulau Jawa). 
Table 1. Variasi harga kayu rakyat di tingkat desa dan kabupaten untuk jenis kayu jati (Gunungkidul) dan sengon (Pati)

\begin{tabular}{|c|c|c|c|c|}
\hline No. & Jenis Kayu & $\begin{array}{l}\text { Kelas } \\
\text { Kualitas }\end{array}$ & $\begin{array}{l}\text { Diameter } \\
(\mathrm{cm})\end{array}$ & $\begin{array}{c}\text { Harga } \\
\left(\text { Rp. } 1.000 / \mathrm{m}^{3}\right)\end{array}$ \\
\hline \multirow[t]{6}{*}{1} & \multirow{6}{*}{$\begin{array}{l}\text { Jati (Tectona } \\
\text { grandis) }\end{array}$} & $\mathrm{A} 1(\mathrm{DL})$ & $<13$ & $500-700$ \\
\hline & & A1 (UP) & $16-19$ & $1.000-1.400$ \\
\hline & & A2 (UD) & $22-28$ & $2.000-2.400$ \\
\hline & & A3 (UGD) & 30 & $3.000-3.500$ \\
\hline & & A4 & 44 & $>4.000$ \\
\hline & & A5 & 54 & $>5.000$ \\
\hline \multirow[t]{8}{*}{2} & \multirow{8}{*}{$\begin{array}{l}\text { Sengon } \\
\text { (Paraserianthes } \\
\text { falcataria (L.) } \\
\text { Nielsen) }\end{array}$} & Panjang & $10-14$ & $395-470$ \\
\hline & & $1,3 \mathrm{~m}$ & $15-19$ & $495-570$ \\
\hline & & & 20 & $695-720$ \\
\hline & & & 25 & $795-875$ \\
\hline & & Panjang & $25-29$ & $800-916$ \\
\hline & & $2,6 \mathrm{~m}$ & $30-39$ & $925-1.100$ \\
\hline & & & $40-49$ & $1.125-1.140$ \\
\hline & & & 50 & $1.125-1.150$ \\
\hline
\end{tabular}
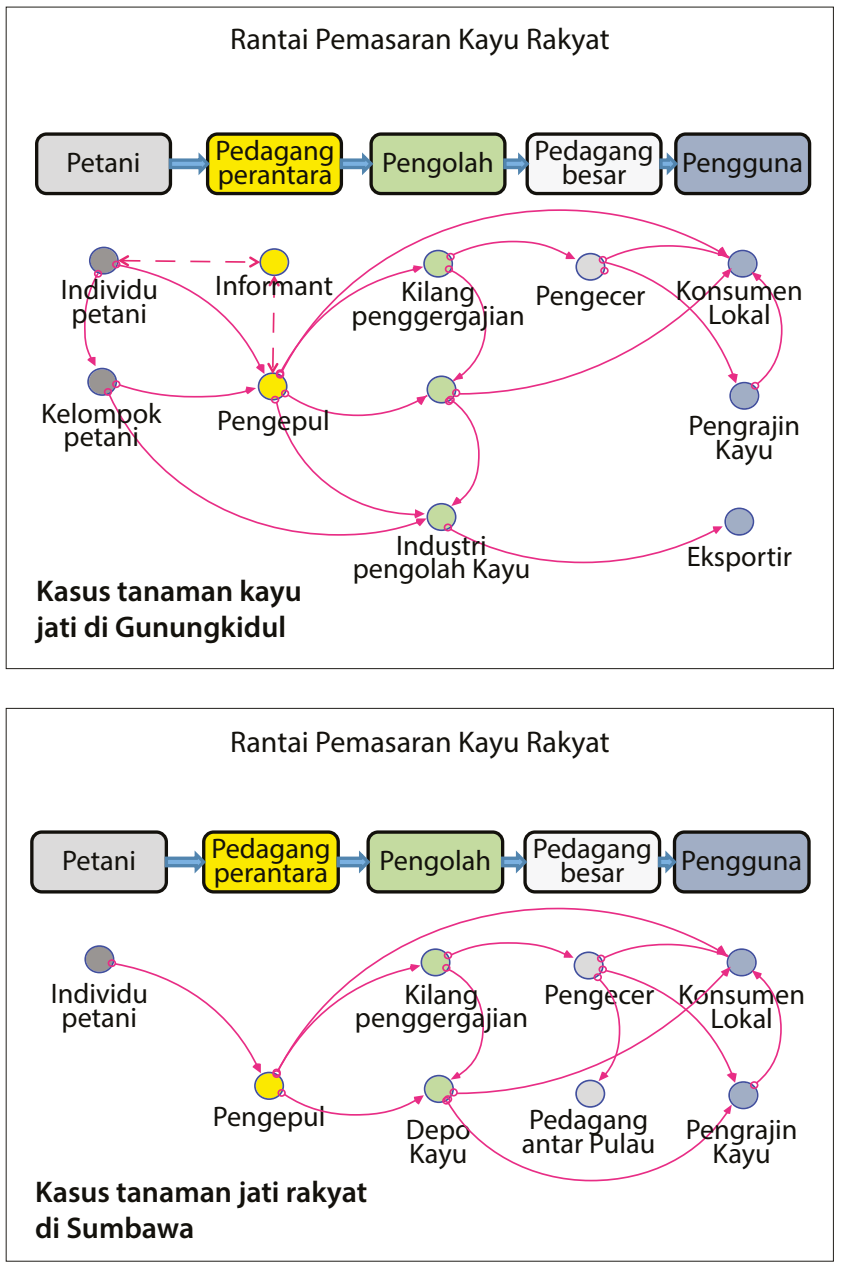

Gambar 2. Perbandingan rantai pasar kayu rakyat di Gunungkidul dan Sumbawa
Pedagang perantara mempunyai peranan penting dalam pemasaran kayu rakyat. Keuntungan yang diperoleh para pedagang perantara tidak selalu lebih besar daripada petani kayu, walaupun mereka dapat memperoleh keuntungan tersebut dalam rentang waktu yang jauh lebih singkat dibandingkan dengan petani kayu (Stewart et al, 2014a).

Peraturan yang terkait dengan izin tebang dan dokumen transpor kayu cenderung menjadi penghambat usaha tanaman kayu rakyat dan menciptakan biaya transaksi tinggi. Di Sumbawa, petani yang akan menjual kayu dari hutan milik harus mengurus bukti kepemilikan atas lahan dengan membayar biaya sertifikat tanah (sekitar Rp 2,5 juta per ha). Sertifikat ini diperlukan untuk mendapatkan izin panen atau Izin Pemanfaatan Kayu Tanah Milik (IPKTM). Selain itu, para pedagang kayu juga harus mengeluarkan biaya untuk mengurus dokumen angkutan kayu dengan harga bervariasi antara Rp100.000,00 hingga Rp 500.000,00 pada setiap transaksi penjualan kayu (sekitar $5 \mathrm{~m}^{3}$ kayu bulat). Di Gunungkidul, proporsi biaya pengurusan dokumen transportasi kayu berkisar antara 7 sampai 13\% dari biaya total pemasaran yang dikeluarkan oleh pedagang perantara. Di Konawe Selatan, biaya tersebut sekitar $32 \%$ dari biaya total pemasaran yang mencakup biaya dokumen angkutan kayu dan pajak pemerintah daerah. Pada umumnya biaya-biaya tersebut menjadi tanggung jawab pedagang perantara, namun sebagai akibatnya mereka akan menekan harga beli kayu dari petani. Oleh karena itu, peraturan tersebut cenderung menjadi disinsentif dan menurunkan minat petani untuk berinvestasi pada usaha tanaman kayu (Stewart et al, 2014a).

Baru-baru ini pemerintah Indonesia telah menerapkan kebijakan Sistem Verifikasi Legalitas Kayu (SVLK) untuk semua kayu yang diproduksi termasuk kayu rakyat. Skema sertifikasi ini bertujuan untuk meningkatkan citra legalitas kayu Indonesia dan agar diterima lebih baik oleh pasar kayu internasional. Penerapan kebijakan ini akan menciptakan biaya transaksi baru kepada petani, karenanya pemerintah harus memberikan insentif untuk mengimbangi biaya tambahan tersebut (Stewart et al, 2014b). Insentif yang mungkin dapat diberikan adalah penghapusan kewajiban atas dokumen SKAU (Surat Asal Usul Kayu) ketika petani kayu rakyat telah mendapatkan dokumen SVLK.

\section{Rekomendasi}

Untuk mengembangkan usaha tanaman kayu rakyat di Indonesia, lembaga pemerintah di tingkat pusat dan daerah yang menangani kegiatan penyuluhan terhadap petani perlu melakukan berbagai upaya berikut:

- meningkatkan kemampuan dan keterampilan petani dalam pemasaran kayu, melalui kegiatan pelatihan guna meningkatkan pengetahuan petani tentang pasar, kualitas kayu yang dibutuhkan industri, serta variasi harga kayu menurut kualitasnya;

- meningkatkan keterampilan petani dalam teknik silvikultur - memfasilitasi pelatihan pengelolaan tanaman kayu rakyat. Kaum perempuan perlu dilibatkan di dalam pelatihan tersebut mengingat peranannya yang juga penting di dalam pengelolaan tanaman;

- memperkuat kapasitas petani dalam melakukan pemasaran kayu secara berkelompok, melalui kegiatan pelatihan untuk mengembangkan usaha bersama dan membangun hubungan bisnis antara kelompok petani dengan industri kayu. Pelatihan di bidang sertifikasi kayu dapat dijadikan sebagai titik awal bagi peningkatan kemampuan petani dalam menjalankan usaha bersama. 
Kementerian Lingkungan Hidup dan Kehutanan perlu menyederhanakan aturan tata niaga kayu dengan mengintegrasikan kewajiban dokumen SVLK dan SKAU. Kelompok tani yang telah memperoleh sertifikat SVLK agar dibebaskan dari kewajiban untuk mengurus SKAU. Kebijakan ini akan mengurangi biaya transaksi pemasaran kayu dan memberikan insentif bagi petani untuk terlibat di dalam program sertifikasi kayu.

\section{Pustaka}

Peraturan Menteri Kehutanan No. P.01/Menhut-II/2004 tentang pemberdayaan masyarakat lokal di dalam dan sekitar areal hutan pada perhutanan sosial. Jakarta: Kementerian Kehutanan Republik Indonesia.

Oktalina SN, Bisjoe AR, Muin N, Purwanti R, Sumirat BK, Putro WT, Utomo S, Nugroho P, Manalu P, Rohadi D, Waka AK, Irawanti S, Pramestisuka A, Syafii S, Julmansyah. 2014. Forestry livelihood framework. Report of Research Task \#2, ACIAR Project FST/2008/030 - Overcoming constraints to community-based commercial forestry in Indonesia. Canberra: Australian Centre for International Agricultural Research.2

Rohadi D. Roshetko JM, Perdana A, Blyth M, Nuryartono N, Kusumowardani N, Pramono AA, Widyani N, Fauzi A, Sasono J, Sumardamto P, Manalu P. 2012. Improving economic outcomes for smallholders growing teak in agroforestry systems in Indonesia. Final Report ACIAR Project FST/2005/177. Canberra: Australian Centre for International Agricultural Research.

Stewart HTL, Rohadi D. Manalu P, Herawati T, Oktalina SN, Rohman, Putro WT, Utomo S, Ningrum LW, Hidayat R, Irawanti S, Pramestisuka A, Parlinah N, Bisjoe AR, Muin N, Hayati N, Waka AK, Sumirat BK, Syafii S, Julmansyah, Aryanti ND, Waluyadi YK, Darisman A, Silvia D. 2014a. Research Task 3: Evaluation of the dominant business models of community-based commercial forestry being implemented by government and the private sector. Report of a study conducted in Gunungkidul, Pati, Bulukumba, Konawe Selatan and Sumbawa, ACIAR Project FST/2008/030 - Overcoming constraints to community-based commercial forestry in Indonesia. Canberra: Australian Centre for International Agricultural Research, $46 \mathrm{pp}$.

Stewart HTL, Rohadi D and Irawanti S. 2014b. Special study into the outcomes of forest certification for smallholder forest growers. Report of a study conducted in Gunungkidul and Pati, ACIAR Project FST/2008/030 - Overcoming constraints to community-based commercial forestry in Indonesia. Canberra: Australian Centre for International Agricultural Research.

Van de Fliert E. 2013. Social dimension analysis of community based commercial forestry in Indonesia. Report on study conducted in Gunungkidul, Pati, Bulukumba, Konawe Selatan and Sumbawa. ACIAR Project FST/2008/030 - Overcoming constraints to community-based commercial forestry in Indonesia.

\section{Ucapan terimakasih}

Info Brief ini merupakan salah satu hasil kegiatan kerjasama antara peneliti CIFOR dengan mitra yang terlibat dalam kegiatan penelitian ACIAR FST/2008/030 "Overcoming Constraints to Community-Based Commercial Forestry in Indonesia".

CIFOR mengucapkan terima kasih kepada Australian Centre for International Agricultural Research (ACIAR) atas dukungan pendanaan proyek penelitian ini, serta semua lembaga mitra termasuk Australia National University; Badan Litbang dan Inovasi, Kementerian Lingkungan Hidup dan Kehutanan Indonesia; Universitas Gajah Mada; World Wide Fund for Nature (WWF) Nusa Tenggara; Trees for Trees; Pemerintah Daerah di Kabupaten Gunungkidul, Pati, Sumbawa, Bulukumba dan Konawe Selatan; serta kelompok masyarakat yang membantu pelaksanaan kegiatan penelitian ini. CIFOR juga berterima kasih kepada Christopher Beadle yang telah memberikan masukan atas penulisan info brief ini.

Informasi lebih lanjut tentang proyek penelitian CBCF dapat diakses di http://puspijak.org/aciar.

Tim peneliti yang berkontribusi dalam penyusunan Info Brief ini (dalam urutan abjad) terdiri dari: Abdul Kadir Waka; Achmad Darisman; Achmad Rizal Bisjoe; Aneka Prawesti Suka; Bugi Kabul Sumirat; Devi Silvia; Julmansyah; Kirsfianti Ginoga; Linda Wige Ningrum; Novita Diah Aryanti; Nunung Parlinah; Nur Hayati; Nurhaedah Muin; Philip Manalu; Rochmad Hidayat; Rohman; Setiasih Irawanti; Silvi Nur Oktalina; Singgih Utomo; Syafrudin Syafii; Wiyono T. Putro; dan Yuwono Kamil Waluyadi.

\begin{tabular}{|c|c|c|}
\hline CGIAR & $\begin{array}{l}\text { PROGRAM } \\
\text { PENELITIAN PADA } \\
\text { Hutan, Pohon dan } \\
\text { Wanatani }\end{array}$ & $\begin{array}{l}\text { Penelitian ini dilaksanakan oleh CIFOR sebagai bagian dari Program Penelitian CGIAR pada Hutan, } \\
\text { Pohon dan Wanatani (CRP-FTA). Program kolaboratif ini bertujuan untuk meningkatkan pengelolaan } \\
\text { dan pemanfaatan hutan, wanatani, dan sumber daya genetis pohon yang mencakup lanskap dari } \\
\text { hutan sampai ke lahan budidaya. CIFOR memimpin CRP-FTA melalui kemitraan dengan Bioversity } \\
\text { International, CATIE, CIRAD, International Center forTropical Agriculture dan World Agroforestry Centre. }\end{array}$ \\
\hline
\end{tabular}

CGIAR

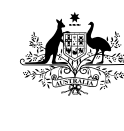

Australian Government

Australian Centre for International Agricultural Research

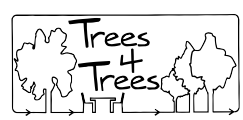

THE AUSTRALAN NATIONAL UNIVERSIT

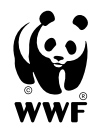

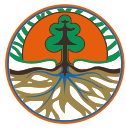

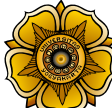

